\title{
PENAMPILAN KARAKTER AGRONOMI 16 GENOTIP KEDELAI (Glycine max L. Merrill) PADA PERTANAMAN TUMPANGSARI DENGAN JAGUNG (Zea mays L.) POLA 3:1
}

\section{APPEARANCE OF AGRONOMIC CHARACTERS OF 16 SOYBEAN GENOTYPES (Glycine max L. Merrill) IN INTERCROPPING WITH CORN (ZEA MAYS L.) 3: 1 PATTERN}

\author{
Acep Atma Wijaya ${ }^{\left.1)^{*}\right)}$, Hana D. Rahayu ${ }^{2)}$, Adi Oksifa. R. $\mathrm{H}^{1)}$, Meddy Rachmadi ${ }^{3)}$ dan Agung \\ Karuniawan $^{3)}$ \\ ${ }^{1)}$ Staf Pengajar Program Studi Agroteknologi Fakultas Pertanian Universitas Majalengka \\ ${ }^{2)}$ Mahasiswa Program Studi Agroteknologi Fakultas Pertanian Universitas Majalengka \\ Jl. K. H. Abdul Halim, No. 103. Majalengka \\ ${ }^{3)}$ Staf Pengajar Program Studi Agronomi Fakultas Pertanian Universitas Padjadjaran \\ Jln.Raya Bandung - Sumedang Km. 21 Jatinangor
}

Korespondensi : acepatma_wijaya@yahoo.co.id

Diterima 5 Desember 2015/ Disetujui 30 Desember 2015

\begin{abstract}
ABSTRAK
Kedelai merupakan komoditas pertanian yang sangat penting di Indonesia. Namun, produksi kedelai nasional belum dapat memenuhi kebutuhan kedelai nasional. Upaya yang dapat dilakukan adalah dengan menerapkan pola tanam tumpangsari kedelai dengan jagung. Penelitian ini bertujuan untuk mencari genotip kedelai yang mampu beradaptasi pada pertanaman tumpangsari dengan jagung pola 3:1 serta menghitung produktivitas penggunaan lahan setiap genotip pada pertanaman tumpangsari dengan jagung pola 3:1. Penelitian ini menggunakan metode eksperimen Rancangan Acak Kelompok (RAK). 16 genotip kedelai digunakan sebagai perlakuan, dan diulang sebanyak dua kali. Untuk melihat respons genotip pada pertanaman tumpangsari dilakukan dengan uji Least Significant Increase (LSI) pada taraf signifikansi $5 \%$. Pendugaan produktivitas lahan pada setiap genotip dihitung berdasarkan nilai Nisbah Kesetaraan Lahan. Hasil penelitian ini menunjukkan genotip kedelai yang memperlihatkan respons paling baik pada pertanaman tumpangsari kedelai jagung dibandingkan kultivar cek untuk tinggi tanaman yaitu genotip BTN 5 dan JT 3, karakter jumlah cabang produktif yaitu genotip BTN 5 , karakter luas daun dan indeks luas daun yaitu genotip JT 3 , karakter sudut daun yaitu genotip CK 6, karakter bobot per plot yaitu genotip KBI 2, dan Nisbah Kesetaraan Lahan yaitu genotip CK 6 dan KBI 2.Genotip BTN 1, BTN 2, BTN 5, CK 15, CK 6, JT 3, KA 6, KA 7, KBI 2, KH 8, Cikuray dan Malikka memiliki nilai NKL lebih besar dari 1,0.
\end{abstract}

Kata kunci: Genotip kedelai, Nisbah Kesetaraan Lahan, Tumpangsari

\begin{abstract}
Soybean is one of important agricultural commodity in Indonesia. However, the national soybean production is not sufficient to meet the needs of national soybean. Effort to do is by applying an intercropping soybean with corn. The objectives of the research was to find soybean genotypes that can adapt to intercropped plantation with corn in pattern of $3: 1$ as
\end{abstract}


well as the productivity of the land use of each genotype in intercropping with maize in $3: 1$ pattern. The research used an experimental method randomized block design (RBD), 16 soybean genotypes as treatments, and repeated twice. To see the response of genotype in intercropping planting was done by using Least Significant Increase (LSI) at the level of significant $5 \%$. Estimation of land productivity on each genotype was calculated with Land Equation Ratio value. The results showed that the best response of soybean genotype compared checks cultivar for plant height were genotype BTN 5 and JT 3, character number of productive branches was genotype BTN 5, the character of leaf area and leaf area index was genotype JT 3 , leaf angle character was genotype CK 6 , characters of weights per plot was KBI 2 genotype and Land Equation Ratio value were CK 6 and KBI 2. Genotypes of BTN 1, BTN 2, BTN 5, CK 15, CK 6, JT 3, KA 6, KA 7, KBI 2, KH 8, Cikuray and Malikka had Land Equivalent Ratio values greater than 1.0.

Key words : Intercropping, Land Equivalent Ratio, Soybean Genotype

\section{PENDAHULUAN}

Di Indonesia, kedelai dijadikan sebagai bahan pangan untuk memenuhi kebutuhan protein masyarakat Indonesia. Kandungan protein biji kedelai per 100 gram biji kedelai mengandung $40 \%$ sampai $45 \%$ protein (FAO, 1990). Kedelai dapat dimakan langsung sebagai kedelai rebus atau kacang kedelai goreng, selain itu kedelai dapat di olah menjadi tempe, tahu, tauco, dan susu kedelai. Kedelai juga dapat diekstrak sebagai bahan baku industri minyak kedelai (Supriono, 2000). Tanaman kedelai baik itu kering maupun tanaman kedelai segar dapat dijadikan pula sebagai bahan pakan ternak. Sisa tanaman kedelai segar maupun kering dapat dijadikan pupuk hijau karena banyak mengandung nitrogen yang dibutuhkan oleh tanaman (Rachman, dkk., 2010).

Berdasarkan catatan Badan Pusat Statistik (2015), pada tahun 2004 produksi nasional mencapai 723.483 ton dengan luas panen 565.155 hektar, kemudian tahuntahun selanjutnya produksi kedelai nasional menunjukkan fluktuasi naik turun. Produktivitas kedelai nasional masih sekitar 1,3 ton/ha. Hal ini masih jauh dari potensi produktivitas kedelai unggul (Purnima, et al., 2014). Upaya untuk mencukupi kebutuhan nasional, maka harus mengimpor kedelai dari luar. Negara pengekspor kedelai ke Indonesia diantaranya Cina, Jepang, Amerika dan Brasil.

Penanaman kedelai dengan sistem tumpangsari, akan berbeda dibandingkan dengan penanaman kedelai dengan sistem tunggal kedelai. Pada pertanaman tumpangsari akan terjadi kompetisi antara tanaman kedelai dengan tanaman sampingnya. Kompetisi tersebut dapat berupa kompetisi mendapatkan unsur hara, cahaya matahari, ruang tumbuh dan lainlain. Cahaya matahari yang diterima tanaman kedelai pada sistem pertanaman tumpangsari sangat rendah, hal ini dapat mempengaruhi pertumbuhan dan hasil tanaman kedelai (Lukitasari, 2006).

Penanaman kedelai secara tumpangsari biasa dilakukan petani dengan tanaman jagung. Penanaman tumpangsari jagung dan kedelai sudah dilakukan di indonesia. Jagung yang digunakan untuk tumpangsari biasanya berasal dari populasi jagung lokal, kultivar bersari bebas, atau hibrida. Kedelai yang digunakan biasanya kultivar unggul 
yang khusus beradaptasi pada naungan. Kultivar Argopuro dan Wilis merupakan contoh kultivar kedelai yang mampu beradaptasi terhadap cahaya rendah (Balai Penelitian Kacang-Kacangan dan UmbiUmbian, 2009).

Masih sedikitnya kultivar kedelai yang tahan terhadap cahaya rendah menjadikan sedikitnya kultivar yang dapat dipilih oleh petani dalam budidaya kedelai sistem tumpangsari dengan jagung. Dalam pengembangan kultivar kedelai yang tahan naungan, Laboratorium Pemuliaan Tanaman Fakultas Pertanian Universitas Padjadjaran memiliki beberapa galur harapan kedelai yang potensi hasil tinggi untuk dikembangkan dan diuji pada pertanaman tumpangsari dengan jagung. Dalam percobaan ini dipakai 16 galur harapan kedelai untuk diuji dalam lingkungan pertanaman tumpangsari dengan jagung

\section{BAHAN DAN METODE}

Percobaan ini dilaksanakan di Desa Leuweunggede, Kecamatan Jatiwangi Kabupaten Majalengka. Lahan yang digunakan dalam percobaan ini adalah sawah irigasi bekas tanaman padi. Bahan yang digunakan dalam penelitian ini adalah 16 genotip harapan kedelai koleksi Laboratorium Pemuliaan Tanaman Fakultas Pertanian Universitas Padjadjaran. Kultivar jagung yang digunakan adalah jagung hibrida kultivar Pertiwi 2.

Rancangan analisis yang digunakan dalam percobaan ini adalah Rancangan Acak Kelompok (RAK) pola biasa. Perbedaan pengaruh perlakuan diuji dengan uji $\mathrm{F}$ pada taraf 5\%. Untuk mengetahui perbedaan respon setiap genotip dibandingkan kultivar cek, maka dilakukan uji LSI (Least Significant Increase) menurut Petersen (1994)

$$
L S I=t_{(0,05 ; d b)} \sqrt{\frac{2 M S E}{n}}
$$

Keterangan :

$\mathrm{t}_{(0,05 ; \mathrm{db})}=$ nilai $\mathrm{t}$ tabel satu arah pada taraf $5 \%$

MSE = Kuadrat Tengah Galat

$\mathrm{n} \quad=$ Jumlah ulangan

Untuk mengetahui indeks penggunaan lahan pada pertanaman tumpangsari kedelai dengan jagung digunakan rumus menurut Petersen (1994), sebagai berikut:

$$
N K L=\sum_{t=i}^{n} \frac{Y_{i}}{Y_{i i}}=\left[\left(\frac{A_{x}}{A_{y}}\right)+\left(\frac{M_{x}}{M_{y}}\right)\right]
$$

Keterangan :

$Y_{i}=$ hasil kedelai ditambah jagung pada tumpangsari

$\mathrm{Y}_{\mathrm{ii}}=$ hasil kedelai ditambah jagung pada pertanaman tunggal

$A_{x}=$ hasil tanaman kedelai pada tumpang sari

$A_{y}=$ hasil tanaman kedelai pada tanam tunggal

$\mathrm{M}_{\mathrm{x}}=$ hasil tanaman jagung pada tumpangsari

$\mathrm{M}_{\mathrm{y}}=$ hasil tanaman jagung pada tanam tunggal

Karakter yang diamati dalam penelitian ini adalah tinggi tanaman, jumlah cabang produktif, luas daun, kandungan klorofil daun, jumlah daun, sudut daun, jumlah polong hampa per tanaman, jumlah polong isi per tanaman, jumlah biji per tanaman, bobot biji per tanaman, bobot 100 butir, dan bobot biji per plot. 


\section{HASIL DAN PEMBAHASAN}

\section{Tinggi Tanaman (cm), Jumlah Cabang Produktif, Kandungan Klorofil Daun, dan Jumlah Daun}

Tabel 1 menunjukkan hasil 13 genotip kedelai dibandingkan dengan tiga kultivar cek untuk karakter tinggi tanaman, jumlah cabang produktif, kandungan klorofil daun dan jumlah daun.

Tabel 1 menunjukkan bahwa penampilan 13 genotip kedelai tidak memperlihatkan hasil lebih baik dibandingkan kultivar cek Arjasari dan Malikka untuk tinggi tanaman (cm) berdasarkan uji LSI pada taraf 5\%. Genotip BTN $5(47,13 \mathrm{~cm})$ dan JT $3(48,69$ $\mathrm{cm})$ menunjukkan hasil tinggi tanaman yang lebih tinggi dibandingkan kultivar cek Cikuray $(37,72 \mathrm{~cm})$ berdasarkan uji LSI pada taraf 5\%. Tinggi tanaman pada kultivar cek Arjasari dan Malikka yaitu 42,85 cm dan $46,96 \mathrm{~cm}$ dengan nilai LSI 7,81. Tinggi tanaman genotip-genotip kedelai berkisar antara $36,33 \mathrm{~cm}$ sampai $48,69 \mathrm{~cm}$.

Pada penanaman kedelai secara tumpangsari dengan jagung, tanaman kedelai akan mendapatkan cekaman naungan. Cekaman naungan tersebut diakibatkan karena penutupan kanopi oleh tanaman jagung. Pada keadaan seperti ini pertumbuhan tanaman kedelai akan tidak optimal. Tinggi tanaman merupakan karakter yang dapat dilihat dengan mudah sebagai penciri adaptasi tanaman kedelai terhadap cekaman cahaya rendah. Tanaman kedelai yang mendapat naungan akan menunjukkan pertumbuhan tinggi tanaman yang lebih tinggi dibandingkan dalam kondisi cahaya penuh karena batang tanaman mengalami etiolasi (Uchimiya, 2001). Hal ini diakibatkan dari pemanjangan antar ruas batang kedelai yang mendapat cekaman naungan. Pemanjangan antar ruas batang ini akibat dari pemanjangan molekul protein pada dinding sel (Liu, dkk., 2011). Keadaan morfologi tanaman yang lebih tinggi akan mengakibatkan tanaman mudah rebah sehingga dapat menurunkan hasil biji.

Tabel 1 menunjukkan penampilan genotip kedelai berbeda-beda pada pertanaman tumpangsari dengan jagung. Perbedaan penampilan tersebut diakibatkan karena kemampuan toleransi terhadap cahaya rendah yang berbeda-beda (Fu, dkk., 2011). Genotip kedelai yang diindikasikan sangat toleran pada lingkungan ternaungi dicirikan oleh tanaman lebih tinggi dibandingkan pada kondisi tanpa naungan tetapi tanaman tidak roboh (Susanto dan Titik, 2011).

Penampilan 13 genotip kedelai menunjukkan tidak lebih baik terhadap kultivar cek Cikuray dan Arjasari untuk karakter jumlah cabang produktif, kandungan klorofil daun dan jumlah daun (Tabel 1). Genotip BTN 5 nyata menunjukkan penampilan yang lebih baik dibandingkan kultivar cek Malikka, sedangkan pada karakter kandungan klorofil dan jumlah daun semua genotip menunjukkan penampilan yang tidak lebih baik dari kultivar cek.

Genotip yang toleran terhadap intensitas cahaya rendah dapat dilihat dari karakter kandungan klorofil daun dan karakter daun yang lainnya. Penampilan genotip menunjukkan bahwa semua genotip yang diuji tidak menunjukkan penampilan yang lebih baik dibandingkan tiga kultivar cek yaitu Arjasari, Cikuray dan Malikka. Daun sebagai organ utama tanaman dalam proses fotosintesis dan menentukan aktivitas fotosintetik optimum melalui berbagai mekanisme bentuk adaptasi terhadap cahaya rendah. Jumlah klorofil dan jumlah 
daun yang banyak memungkinkan tanaman dapat menangkap cahaya matahari lebih banyak serta disintesis menjadi karbohidrat. Hasil penelitian Lukitasari (2006) menunjukkan bahwa, pada naungan $75 \%$ jumlah daun menjadi berkurang sehingga indeks luas daun juga akan lebih kecil. Akibat dari berkurangnya jumlah daun, maka proses fotosintesis yang terjadi akan lebih sedikit.

Tabel 1. Penampilan 16 Genotip Kedelai pada Pertanaman Tumpangsari dengan Jagung Untuk Karakter Tinggi Tanaman (cm), Jumlah Cabang Produktif, Kandungan Klorofil Daun, dan Jumlah Daun

\begin{tabular}{|c|c|c|c|c|}
\hline Genotipe & $\begin{array}{l}\text { Tinggi Tanaman } \\
\text { (cm) }\end{array}$ & $\begin{array}{l}\text { Jumlah Cabang } \\
\text { Produktif }\end{array}$ & $\begin{array}{l}\text { Kandungan } \\
\text { Klorofil Daun }\end{array}$ & $\begin{array}{c}\text { Jumlah } \\
\text { Daun }\end{array}$ \\
\hline BTN 1 & 38,32 & 3,40 & 41,74 & 18,40 \\
\hline BTN 2 & 38,19 & 3,70 & 39,93 & 18,30 \\
\hline BTN 5 & 47,13 & 4,90 & 43,27 & 31,00 \\
\hline CK 0 & 37,49 & 3,70 & 43,36 & 22,60 \\
\hline CK 15 & 36,33 & 3,50 & 44,04 & 16,50 \\
\hline CK 5 & 38,38 & 3,40 & 41,64 & 15,60 \\
\hline CK 6 & 36,50 & 4,10 & 41,72 & 25,60 \\
\hline JT 3 & 48,69 & 4,20 & 45,95 & 19,70 \\
\hline KA 6 & 45,33 & 3,50 & 44,59 & 22,50 \\
\hline KA 7 & 44,40 & 4,30 & 42,79 & 21,90 \\
\hline KBI 2 & 41,60 & 2,90 & 44,61 & 24,90 \\
\hline KH 8 & 37,67 & 3,80 & 44,86 & 25,50 \\
\hline SM 2 & 43,37 & 4,30 & 39,89 & 24,80 \\
\hline ARJASARI & 42,85 & 4,60 & 47,56 & 24,70 \\
\hline CIKURAY & 37,72 & 4,40 & 44,47 & 30,90 \\
\hline MALIKA & 46,96 & 3,10 & 44,54 & 23,80 \\
\hline LSI & 7,81 & 1,25 & 4,29 & 7,33 \\
\hline
\end{tabular}

Keterangan : $a=$ berbeda nyata dengan kultivar Arjasari berdasarkan LSI 5\%, c = berbeda nyata dengan Cikuray berdasarkan LSI 5\%, $\mathrm{m}$ = berbeda nyata dengan Malikka berdasarkan LSI 5\%

2. Luas Daun $\left(\mathrm{cm}^{2}\right)$, Indeks Luas Daun, Sudut Daun $\left({ }^{\circ}\right)$, dan Jumlah Polong Hampa

Hasil analisis statistik menunjukkan bahwa tidak terjadi keragaman antara semua genotip yang diuji pada karakter luas daun, indeks luas daun, sudut daun, dan jumlah polong per tanaman. Penampilan genotip yang diuji dibandingkan dengan kultivar cek dilakukan dengan uji LSI pada taraf 5\%. Hasil uji LSI pada taraf 5\% dapat dilihat pada Tabel 2.
Tabel 2 menunjukkan bahwa penampilan semua genotip dibandingkan dengan kultivar cek Arjasari dan Cikuray menunjukkan penampilan yang tidak lebih baik untuk karakter luas daun dan indeks luas daun. Genotip JT 3 menunjukkan respon lebih baik dibandingkan kultivar cek Malikka. Hal ini diduga karena kultivar cek Arjasari dan Cikuray memiliki bentuk daun yang lebar sehingga luas daun dari kedua kultivar cek ini lebih besar dibandingkan semua genotip yang diuji (Arjasari $=33,61$, 
dan Cikuray $=31,89)$. Luas daun yang semakin tinggi dan jumlah daun yang semakin banyak maka permukaan daun yang dapat menerima cahaya matahari akan lebih banyak sehingga tempat untuk berlangsungnya proses fotosintesis akan lebih besar. Tanaman dengan daun yang sempit dan menggulung dengan sudut daun lebih kecil dari $60^{\circ}$ akan menerima cahaya matahari lebih sedikit dibandingkan dengan dengan daun yang lebar dan sudut daun lebih besar dari $60^{\circ}$ (Sitompul dan Guritno, 1995).
Tabel 2 menunjukkan bahwa genotip CK 6 menunjukkan penampilan yang lebih baik dibandingkan dengan kultivar cek Arjasari, Cikuray dan Malikka untuk karakter sudut daun. Dilihat dari sudut daunnya, genotip CK 6 memiliki sudut daun lebih besar dari $60^{\circ}$. Sudut daun yang semakin besar, pada pertanaman tumpangsari kedelai dengan jagung memungkinkan tanaman kedelai untuk mendapat cahaya matahari lebih besar dibandingkan dengan sudut daun pada posisi tegak.

Tabel 2. Penampilan 16 Genotip pada Karakter Luas Daun $\left(\mathrm{cm}^{2}\right)$, Indeks Luas Daun, Sudut Daun $\left({ }^{0}\right)$, dan Jumlah Polong Hampa

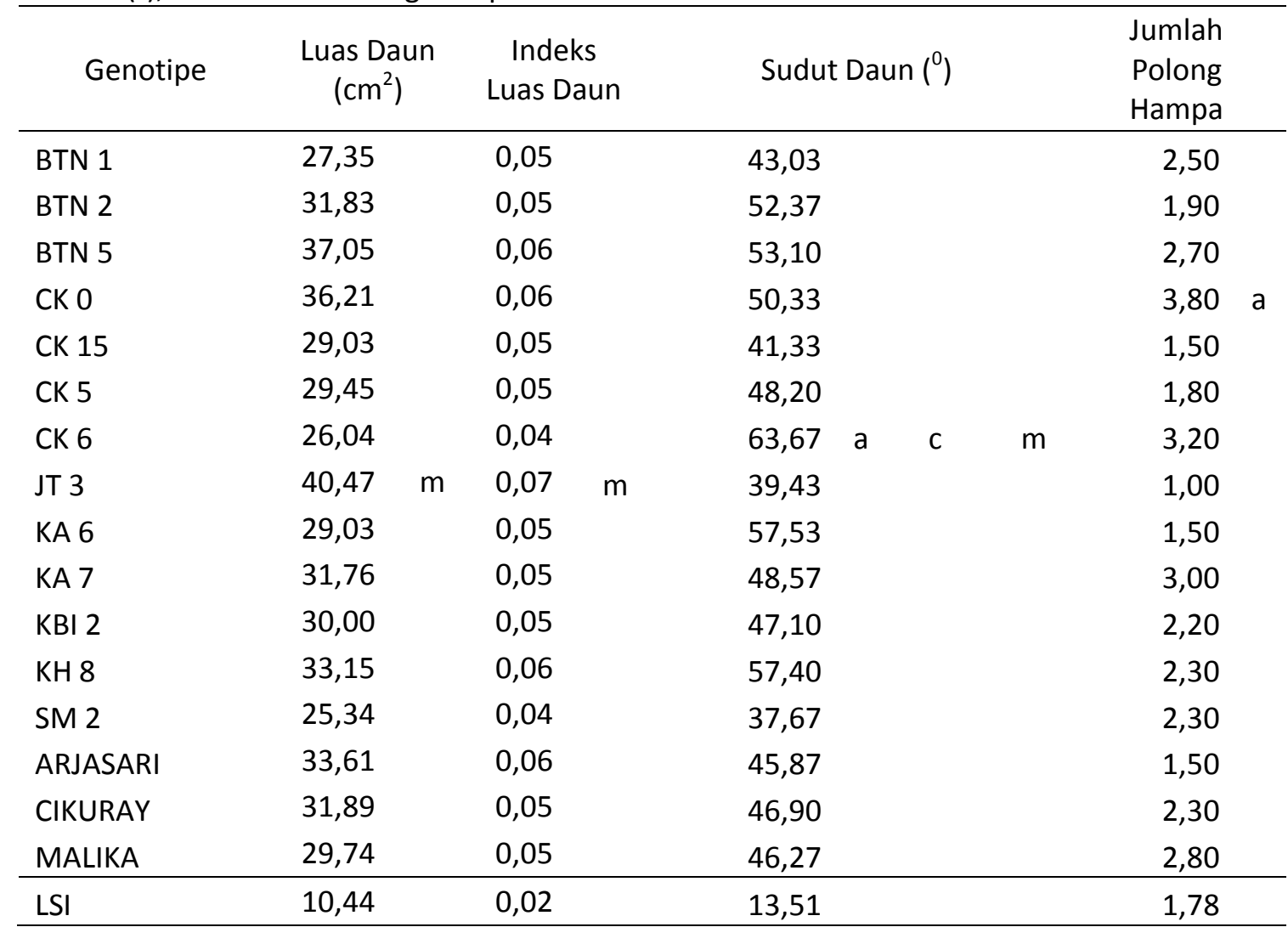

Keterangan: $\mathrm{a}=$ berbeda nyata dengan kultivar Arjasari berdasarkan LSI 5\%, $\mathrm{c}=$ berbeda nyata dengan Cikuray berdasarkan LSI 5\%, $\mathrm{m}$ = berbeda nyata dengan Malikka berdasarkan LSI 5\%.

Penampilan genotip terhadap jumlah polong hampa per tanaman menunjukkan bahwa genotip CK 0 memiliki jumlah polong hampa yang lebih banyak dibandingkan dengan kultivar cek Arjasari, sedangkan genotip lain memiliki jumlah polong hampa yang tidak lebih baik dibandingkan dengan kultivar cek Arjasari, Cikuray, dan Malikka. Polong hampa terjadi karena proses pengisian biji tidak sempurna. Sistem tanam 
secara tumpangsari dengan jagung tanaman kedelai akan mendapat cekaman lingkungan berupa naungan. Menurut Widiastuti, dkk. (2004), naungan dapat mempercepat umur berbunga maupun umur panen. Hal inilah yang diduga menyebabkan jumlah polong hampa pada genotip kedelai yang peka terhadap naungan akan semakin banyak karena proses pengisian polongnya tidak sempurna.

\section{Jumlah Polong Isi per Tanaman, Jumlah Biji per Tanaman, Bobot Biji per Tanaman (g), dan Bobot 100 Butir (g)}

Hasil analisis statistik menunjukkan bahwa tidak terjadi keragaman antar genotip pada karakter jumlah polong isi per tanaman, jumlah biji per tanaman, dan bobot biji per tanaman dan terjdai keragaman antar genotip pada karakter bobot 100 butir. Penampilan genotip yang diuji dibandingkan dengan kultivar cek dilakukan dengan uji LSI pada taraf 5\%. Hasil uji LSI pada taraf $5 \%$ dapat dilihat pada Tabel 3.

Tabel 3. Penampilan 16 Genotip untuk Jumlah Polong Isi per Tanaman, Jumlah Biji per Tanaman, Bobot Biji per Tanaman (g), dan Bobot 100 Butir (g)

\begin{tabular}{lcccc}
\hline Genotipe & $\begin{array}{c}\text { Jumlah Polong Isi } \\
\text { per Tanaman }\end{array}$ & $\begin{array}{c}\text { Jumlah Biji per } \\
\text { Tanaman }\end{array}$ & $\begin{array}{c}\text { Bobot Biji per } \\
\text { Tanaman (g) }\end{array}$ & $\begin{array}{c}\text { Bobot 100 } \\
\text { Butir (g) }\end{array}$ \\
\hline BTN 1 & 39,10 & 52,20 & 4,85 & 9,66 \\
BTN 2 & 35,30 & 42,80 & 3,34 & 9,23 \\
BTN 5 & 68,20 & 73,80 & 7,51 & 9,15 \\
CK 0 & 53,40 & 70,10 & 6,32 & 9,42 \\
CK 15 & 32,40 & 44,90 & 3,92 & 8,83 \\
CK 5 & 27,80 & 33,50 & 3,07 & 9,25 \\
CK 6 & 53,50 & 71,00 & 7,54 & 10,14 \\
JT 3 & 58,50 & 89,80 & 6,48 & 7,56 \\
KA 6 & 54,60 & 86,30 & 8,54 & 10,06 \\
KA 7 & 46,10 & 53,80 & 4,75 & 8,69 \\
KBI 2 & 37,00 & 60,60 & 6,60 & 10,90 \\
KH 8 & 40,00 & 49,80 & 4,85 & 10,80 \\
SM 2 & 33,90 & 41,10 & 3,51 & 8,24 \\
ARJASARI & 43,40 & 70,30 & 10,16 & 13,15 \\
CIKURAY & 58,10 & 89,90 & 9,11 & 11,01 \\
MALIKA & 48,30 & 59,60 & 7,65 & 12,09 \\
\hline LSI & 24,5 & 36,14 & 4,14 & 1,02 \\
\hline Ke & & & & 14 \\
\hline
\end{tabular}

Keterangan: a = berbeda nyata dengan kultivar Arjasari berdasarkan LSI 5\%, c = berbeda nyata dengan Cikuray berdasarkan LSI $5 \%, \mathrm{~m}=$ berbeda nyata dengan Malikka berdasarkan LSI 5\%

Tabel 3 menunjukkan bahwa penampilan semua genotip kedelai tidak menunjukkan penampilan yang lebih baik dibandingkan kultivar Arjasari, Cikuray, dan Malikka untuk karakter jumlah polong isi per tanaman, jumlah biji per tanaman, 
bobot biji per tanaman, dan bobot 100 butir pada pertanaman tumpangsari dengan jagung. Pada pertanaman tumpangsari, tanaman kedelai akan mengalami reduksi hasil akibat adanya penaungan (Marvel, dkk., 1993).

Penaungan yang terjadi akan menyebabkan tanaman kedelai mengalami kejenuhan cahaya sehingga laju fotosintesis akan lebih rendah dibandingkan pada lingkungan normal (Bowes, dkk., 1972). Jumlah polong isi, jumlah biji, bobot biji per tanaman, dan bobot 100 butir tanaman cek nyata lebih tinggi dibandingkan genotipgenotip kedelai yang diuji. Hal ini diduga karena kultivar cek memiliki ukuran biji yang lebih besar dari genotip yang diuji. Genotip-genotip yang toleran terhadap naungan tidak mengakibatkan penurunan signifikan pada jumlah polong, ukuran biji, dan hasil biji per tanaman (Soverda, dkk., 2009). Menurut Rachmadi (2002), genotip yang mampu berkompetisi akan memperlihatkan penampilan karakterkarakter yang unggul dan atau kecilnya penyimpangan keunggulan karakter tersebut dibandingkan dengan penampilan pada pertanaman tunggalnya.

\section{Bobot per Plot (g) dan Nisbah Kesetaraan Lahan}

Hasil analisis statistik menunjukkan bahwa terjadi keragaman antar genotip pada karakter bobot biji per plot dan tidak terjdai keragaman antar genotip pada nilai Nisbah Kesetaraan Lahan. Penampilan genotip yang diuji dibandingkan dengan kultivar cek dilakukan dengan uji LSI pada taraf 5\%. Hasil uji LSI pada taraf 5\% dapat dilihat pada Tabel 4.

Tabel 4 menunjukkan bahwa genotip KBI 2 memperlihatkan penampilan yang lebih baik dibandingkan kultivar cek Arjasari untuk karakter bobot biji per plot dan nilai NKL. Genotip CK 6 memperlihatkan penampilan yang lebih baik dibandingkan kultivar cek Arjasari pada nilai NKL. Semua genotip yang diuji tidak memperlihatkan respon yang lebih baik dari kultivar cek Cikuray dan Malikka untuk karakter bobot biji per plot dan nilai NKL.

Penampilan genotip kedelai pada pertanaman tumpangsari dengan jagung pada karakter bobot biji per plot memperlihatkan bahwa genotip KBI 2 memiliki bobot biji per plot paling tinggi (787,50 g). Tumpangsari kedelai dengan jagung pola 3:1 yaitu tiga baris tanaman kedelai dan satu baris tanaman jagung akan menyebabkan cekaman yang terjadi pada barisan tengah tanaman kedelai menjadi berkurang. Dengan berkurangnya cekaman naungan yang terjadi, sehingga tanaman kedelai yang berada pada barisan tengah dapat berproduksi dengan optimal, sehingga dapat menutupi kekurangan hasil tanaman kedelai yang ternaungi. Tumpangsari kedelai dengan jagung pola 3:1 tujuan awalnya adalah untuk mengurangi reduksi hasil yang terjadi pada tanaman kedelai yang tercekam naungan sehingga produksi kedelai masih tetap tinggi.

Nisbah Kesetaraan Lahan (NKL) digunakan sebagai penduga produktivitas lahan antara pertanaman tumpangsari dan tunggal. Tabel 4 menunjukkan bahwa sebanyak 12 genotip yang memperlihatkan nilai NKL lebih besar dari 1,0. Menurut Ghulamahdi, dkk. (2007), suatu pertanaman tumpangsari yang memiliki nilai NKL lebih besar dari 1,0 menunjukkan bahwa pertanaman tumpangsari tersebut memiliki produktivitas lahan yang lebih tinggi dibandingkan dengan pertanaman tunggal. 
12 genotip tersebut yaitu BTN 1, BTN 2, BTN 5, CK 15, CK 6, JT 3, KA 6, KA 7, KBI 2, KH 8, Cikuray dan Malikka. Rata-rata nilai NKL pertanaman tumpangsari pola 3:1 yaitu
1,23 sehingga dapat dikatakan bahwa tumpangsari 3:1 mampu memberikan produktivitas lahan yang lebih baik.

Tabel 4. Penampilan 16 Genotip untuk Karakter Bobot per Plot (g) dan Nisbah Kesetaraan Lahan

\begin{tabular}{lll}
\hline \multicolumn{1}{c}{ Genotipe } & Bobot Biji per Plot (g) & Nisbah Kesetaraan Lahan \\
& & \\
\hline BTN 1 & 750,00 & 1,62 \\
BTN 2 & 500,00 & 1,21 \\
BTN 5 & 700,00 & 1,53 \\
CK 0 & 450,00 & 0,74 \\
CK 15 & 525,00 & 1,18 \\
CK 5 & 562,50 & 0,89 \\
CK 6 & 637,50 & 1,76 \\
JT 3 & 525,00 & 1,11 \\
KA 6 & 425,00 & 1,01 \\
KA 7 & 575,00 & 1,27 \\
KBI 2 & 787,50 & 1,87 \\
KH 8 & 237,50 & 1,03 \\
SM 2 & 375,00 & 0,89 \\
ARJASARI & 600,00 & 0,90 \\
CIKURAY & 750,00 & 1,39 \\
MALIKA & 725,00 & 1,34 \\
\hline LSI & 158,21 & 0,80 \\
\hline
\end{tabular}

Keterangan: $\mathrm{a}=$ berbeda nyata dengan kultivar Arjasari berdasarkan LSI $5 \%, \mathrm{c}=$ berbeda nyata dengan Cikuray berdasarkan LSI 5\%, $\mathrm{m}$ = berbeda nyata dengan Malikka berdasarkan LSI 5\%

\section{SIMPULAN}

Berdasarkan hasil penelitian, maka dapat diambil kesimpulan adalah sebagai berikut:

1. Genotip kedelai yang menunjukkan respons paling baik pada pertanaman tumpangsari kedelai jagung disbandingkan kultivar cek untuk tinggi tanaman yaitu genotip BTN 5 dan JT 3, karakter jumlah cabang produktif yaitu genotip BTN 5, karakter luas daun dan indeks luas daun yaitu genotip JT 3, karakter sudut daun yaitu genotip CK 6, karakter bobot per plot yaitu genotip KBI 2, dan Nisbah Kesetaraan Lahan yaitu genotip CK 6 dan KBI 2.

2. Genotip BTN 1, BTN 2, BTN 5, CK 15, CK 6, JT 3, KA 6, KA 7, KBI 2, KH 8, Cikuray dan Malikka memiliki nilai NKL lebih besar dari 1,0. 


\section{DAFTAR PUSTAKA}

Badan Pusat Statistik. 2015. Luas Panen, Produktivitas, dan Produksi Kedelai Nasional Tahun 2004-2014. http://bps.go.id. [10-2-2015].

Balai Penelitian Kacang-Kacangan Dan Umbi-Umbian. 2009. Galur Kedelai Toleran Naungan. http://balitkabi.litbang.deptan.go.id. [20 $-2-2015]$.

Bowes, G., W.L. Ogren, R.H. Hageman. 1972. Light saturation, photosynthesis rate, RuDP carboxylase activity, and specific leaf weight in soybeans grown under different light intensity. Crop Sci. 12: 77-79.

FAO, 1990. Soybean. Technology of Production Of Edible Flours And Protein Products From Soybeans. http://www.fao.org/docrep/t0532e/t05 32e02.htm. [29-12-2015)

Fu, J., C.H. Li., J.R Zao, Ma Li, and T.X. Liu. 2011. Shade tolerance indices of maize: selection and evaluation. Ying Yong Sang Tai Xue Bao. 20(11):2705-2709.

Ghulamahdi M, Melati M. Murdianto. 2009. Penerapan Teknologi Budidaya Jenuh Air dan Penyimpanan Benih Kedelai Di Lahan Pasang Surut. Laporan Akhir Program Insentif Tahun 2009. Kementerian Riset Dan Teknologi.

Liu Wei-guo, Jiang Tao, She Yue-hui, Yang Feng, Yang Wen-yu. 2011. Preliminary Studi on Physiological Response Mechanism of Soybean (Glycine max) Stem To Shade Stress At Seedling Stage. Chinese Journal of Oil Crop Sciences. 33(2).p141.

Lukitasari, M. 2006. Pengaruh Intensitas Cahaya Matahari terhadap Pertumbuhan Tanaman Kedelai (Glycine max). IKIP PGRI. Madiun.
Marvel, J. N., C. A. Beyrouty, and E. E. Gbur. 1992. Respon of soybean to root and canopy competition. Crop Sci. 32:797801.

Petersen, R. G. 1994. Agricultural field experiments: design and analysis. Marcel Dekker. NY.

Purnima Dewi, Anang D. Santoso dan Fika Idah R. 2014. Skenario kebijakan peningkatan produksi kedelai nasional. Program Kreativitas Mahasiswa. Universitas Brawijaya Malang

Rachmadi, M. 2002. Analisis seleksi dan respon genotip-genotip kedelai pada lingkungan pertanaman tumpangsari kedelai/ jagung. Disertasi Program Pascasarjana. Fakultas Pertanian Universitas Padjadjaran. Bandung (tidak dipublikasikan).

Rachman Achmad, Ai Dariah, Dan Djoko Santoso. 2010. Pupuk Hijau. (Eds) Pupuk Organik Dan Pupuk Hayati. R. D. M. Simanungkalit, Didi Ardi, S., Rasti Saraswati, Diah Setyorini, Dan Wiwik Hartatik. Balai Pustaka, Jakarta.

Sitompul, S.M., dan B. Guritno. 1995. Analisis pertumbuhan tanaman. Gadjah Mada University Press. Yogyakarta.

Soverda, N., Evita, Gusniwati. 2009. Evaluasi dan seleksi varietas kedelai terhadap naungan dan intensitas cahaya rendah. Zuriat 19: 86-97

Supriono, 2000. Pengaruh Dosis Urea Tablet dan Jarak Tanam terhadap Pertumbuhan dan Hasil Kedelai Kultivar Sindoro. Agrosains 2(2): 45.

Susanto, G.W.A., dan Titik Sundari. 2011. Perubahan karakter agronomi aksesi plasma nutfah kedelai dilingkungan ternaungi. J. Agron. Indonesia. 39(1): 16. 
Uchimiya, H. 2001. Genetic engineering for abiotic stress tolerance in plants. SCOPAS.

http://www.sciencecouncil.cgiar.org.

Widiastuti, L., Tohari, E. Sulistyaningsih. 2004. Pengaruh intensitas cahaya dan kadar daminosida terhadap iklim mikro dan pertumbuhan tanaman krisan dalam pot. Ilmu Pertanian. 11: 35-42 